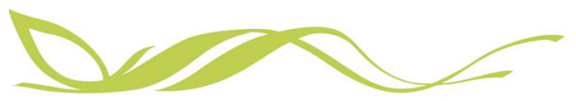

ARTICLE

\title{
Fast and slow components of interstadial warming in the North Atlantic during the last glacial
}

Vasiliki Margari $^{1 凶}$, Luke C. Skinner ${ }^{2}$, Laurie Menviel (10 ${ }^{3}$, Emilie Capron ${ }^{4}$, Rachael H. Rhodes (1) ${ }^{2}$, Maryline J. Mleneck-Vautravers' ${ }^{2}$, Mohamed M. Ezat (10) 2,5,6, Belen Martrat', Joan O. Grimalt (1) ${ }^{7}$, David A. Hodell ${ }^{2} \&$ Polychronis C. Tzedakis (iD) ${ }^{1 凶}$

The abrupt nature of warming events recorded in Greenland ice-cores during the last glacial has generated much debate over their underlying mechanisms. Here, we present joint marine and terrestrial analyses from the Portuguese Margin, showing a succession of cold stadials and warm interstadials over the interval 35-57 ka. Heinrich stadials 4 and 5 contain considerable structure, with a short transitional phase leading to an interval of maximum cooling and aridity, followed by slowly increasing sea-surface temperatures and moisture availability. A climate model experiment reproduces the changes in western lberia during the final part of Heinrich stadial 4 as a result of the gradual recovery of the Atlantic meridional overturning circulation. What emerges is that Greenland ice-core records do not provide a unique template for warming events, which involved the operation of both fast and slow components of the coupled atmosphere-ocean-sea-ice system, producing adjustments over a range of timescales.

\footnotetext{
${ }^{1}$ Environmental Change Research Centre, Department of Geography, University College London, London WC1E 6BT, UK. ${ }^{2}$ Department of Earth Sciences, University of Cambridge, Cambridge CB2 3EQ, UK. ${ }^{3}$ Climate Change Research Centre, PANGEA, The University of New South Wales, Sydney, NSW 2052, Australia. ${ }^{4}$ Physics of Ice, Climate, Earth, Niels Bohr Institute, University of Copenhagen, Tagensvej 16, DK-2200 Copenhagen, Denmark. ${ }^{5}$ CAGE-Centre for Arctic Gas Hydrate, Environment and Climate, Department of Geosciences, UiT The Arctic University of Norway, 9037 Tromsø, Norway. ${ }^{6}$ Department of Geology, Faculty of Science, Beni-Suef University, Beni-Suef, Egypt. ${ }^{7}$ Department of Environmental Chemistry, Institute of Environmental Assessment and

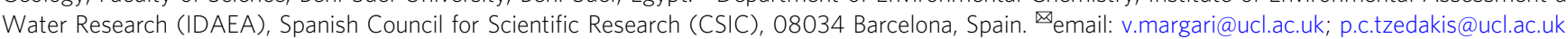


$\mathrm{D}$ uring Marine Isotopic Stage 3 (MIS 3; 59.5-24 thousand years ago [ka]), multiple high-amplitude air-temperature fluctuations (Dansgaard-Oeschger [DO] stadials and interstadials) have been recognized in Greenland ice-cores and linked to sea-surface temperature (SST) variations and intermittent iceberg discharges in the North Atlantic ${ }^{1,2}$. The structure of this variability in Greenland is characterized by a rapid decadal-scale warming at the onset of an interstadial, a gradual cooling within the interstadial and then an abrupt centennialscale cooling leading to stadial conditions ${ }^{3}$. In North Atlantic deep-sea cores, each stadial section contains ice-rafted detritus (IRD) from circum-North Atlantic ice-sheets, with the most prominent peaks (Heinrich layers) associated with iceberg discharges from the Laurentide ice-sheet through the Hudson Strait ${ }^{4-6}$. A distinction has been made between a Heinrich event (HE; the iceberg discharge through Hudson Strait), a Heinrich layer (HL; the physical manifestation of a $\mathrm{HE}$ in a marine sediment core) and a Heinrich stadial (HS; the cold period that contains the HE), underlining the fact that HEs are shorter in duration than the HS in which they occur ${ }^{7,8}$. Ocean circulation tracers indicate that the Atlantic meridional overturning circulation (AMOC) weakened during each stadial, with the most extreme AMOC and SST reductions associated with the largest iceberg discharges ${ }^{9}$.

Millennial-scale changes, bearing distinct similarities to DO variability, have been documented in speleothem and pollen archives downstream from the North Atlantic ${ }^{10-13}$, with intervals corresponding to HS showing the most extreme changes in local climate and vegetation. Atmospheric methane $\left(\mathrm{CH}_{4}\right)$ concentrations in ice-cores also show rapid variations at $50 \%$ of the glacialinterglacial amplitude ${ }^{14}$. The close correspondence with proxy records of low-latitude precipitation has pointed to a significant tropical wetland contribution to changes in atmospheric $\mathrm{CH}_{4}$ concentration, linked to shifts in the mean latitudinal position of the Intertropical Convergence Zone (ITCZ) and associated tropical rain belts ${ }^{15-17}$. High-resolution analyses have also revealed abrupt and sustained $\mathrm{CH}_{4}$ increases during the second part of HS $1,2,4$ and 5, attributed to excess $\mathrm{CH}_{4}$ production from Southern Hemisphere wetlands during extreme southerly displacements of the ITCZ ${ }^{17}$.

Various mechanisms have been proposed to account for the observed millennial-scale changes. Given the evidence for iceberg discharges and ocean changes, a prevalent view has been that freshwater input increased stratification in the North Atlantic and led to a weakening of AMOC with attendant cooling ${ }^{18}$. Meltwater experiments performed with climate models have suggested that the abrupt climate swings could be explained by switches between different AMOC equilibria ${ }^{19-23}$, potentially amplified by a decrease in Laurentide ice-sheet topography ${ }^{24}$. However, one argument for eschewing freshwater forcing has been the simulated slow (centennial-scale) recovery of AMOC and weak temperature response in Greenland, compared to the observed abrupt (decadal-scale) Greenland interstadial transitions $\mathrm{s}^{25}$. Alternative hypotheses have therefore emphasized rapid changes in the coupled atmosphere-ice-ocean system, with simulated retreat of sea-ice in the Nordic Seas able to cause abrupt increases in Greenland air temperatures similar to proxy evidence ${ }^{26}$. Sea-ice retreat has been induced in coupled high-resolution climate models by increasing the height of the Laurentide ice-sheet ${ }^{27}$, changes in atmospheric $\mathrm{CO}_{2}$ concentration ${ }^{28}$, or a saltoscillator $^{29}$.

Establishing the rapidity of changes during interstadial warming transitions in different components of the climate system, therefore, could potentially inform on underlying mechanisms. The Portuguese Margin has been a prime location for investigating millennialscale variability, where analyses of palaeoceanographic and terrestrial proxies from the same samples in marine sequences allow an in situ assessment of the relative timing of changes ${ }^{30-32}$. This is a direct consequence of the geographic setting of the area, where the combined effects of major river systems and a narrow continental shelf lead to the rapid delivery of terrestrial material, including pollen, to the deep-sea environment. Here, we investigate changes in ocean conditions and hydroclimate in the MIS 3 section of the interval 35-57 ka in core MD01-2444 (refs. ${ }^{32-35}$ ). We focus on the sequence of changes during HS4 and HS5 and the transitions into the ensuing interstadials and compare with results from climate model experiments performed with the LOVECLIM Earth System model. The MD01-2444 records show that following peaks in IRD originating from the Hudson Strait during HS4 and HS5, SST and precipitation increased over several centuries, representing a gradual transition into interstadial conditions. The climate model experiment of HS4 reproduces the gradual evolution in SST and precipitation in western Iberia as a result of a slow AMOC recovery, but underestimates the rapidity and magnitude of warming in Greenland, which appears closely related to sea-ice retreat in the Nordic Seas. The results reveal diverse patterns and rates of warming, depending on location and underlying processes.

\section{Results}

MIS 3 changes in MD01-2444. The $\delta^{18} \mathrm{O}$ signal of planktonic foraminifer Globigerina bulloides and the alkenone SST record

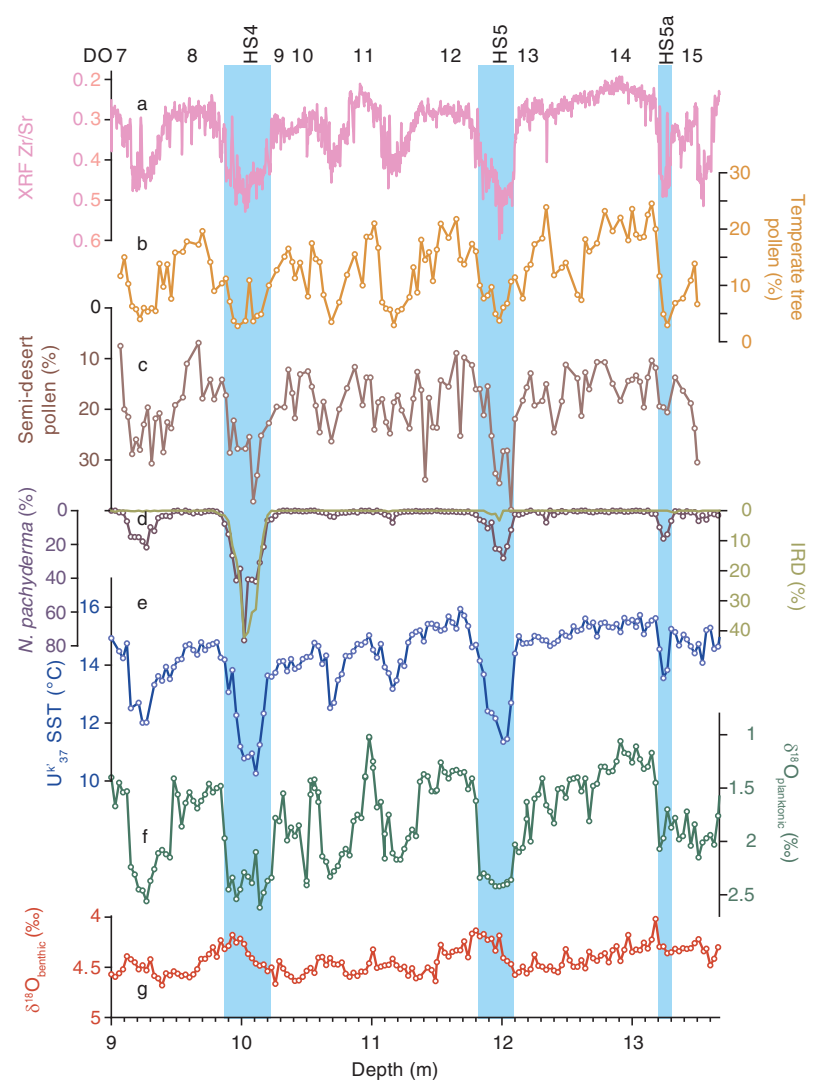

Fig. 1 MD01-2444 MIS 3 records plotted against depth (9-13.67 m). a XRF $\mathrm{Zr} / \mathrm{Sr}$ record (this study). b Temperate (Mediterranean+Eurosiberian) tree pollen percentages (this study). c Pollen percentage of semi-desert taxa (Artemisia and Chenopodiaceae/Amaranthaceae) (inverse scale) (this study). d Percent ice-rafted detritus (IRD) (inverse scale) and Neogloboquadrina pachyderma inverse scale) ${ }^{33}$. e Alkenone-based $U^{k^{\prime}}{ }_{37}$ $\mathrm{SST}^{34}$. f Planktonic (G. bulloides) foraminiferal $\delta^{18} \mathrm{O}$ (ref. ${ }^{33}$ ). $\mathbf{g}$ benthic foraminiferal $\delta^{18} \mathrm{O}$ (ref. ${ }^{32}$ ). DO interstadials are indicated and vertical bars denote HS4, HS5 and HS5a. 


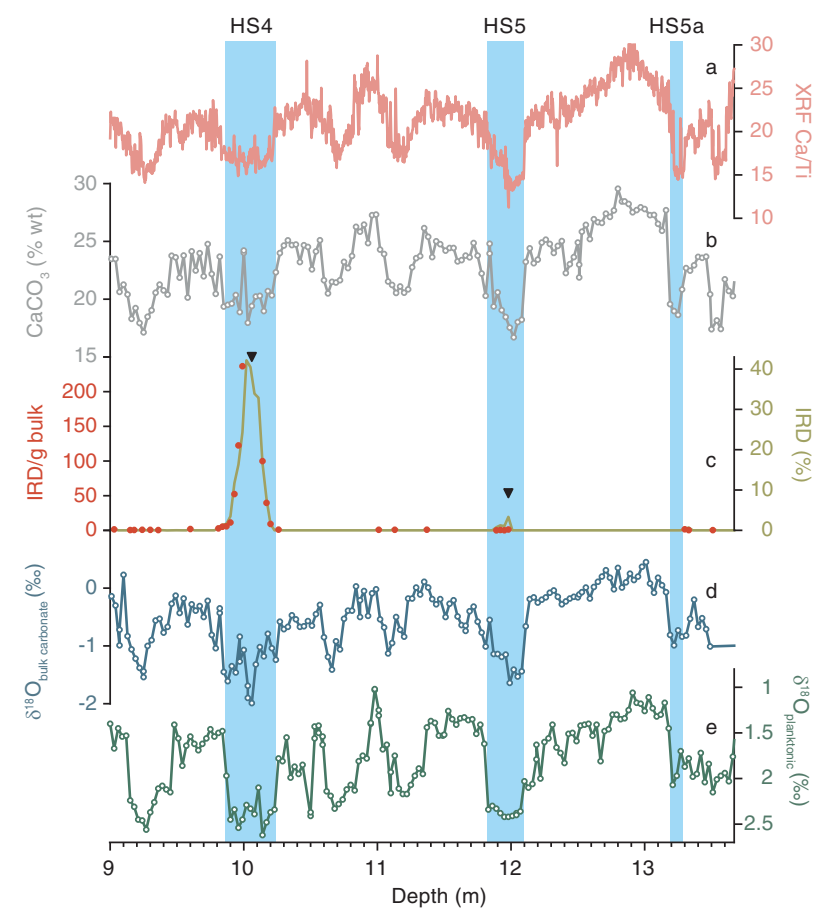

Fig. 2 MD01-2444 MIS 3 records plotted against depth (9-13.67 m). a XRF Ca/Ti record ${ }^{35}$. b Weight percent $\mathrm{CaCO}_{3}$ (ref. ${ }^{35}$ ). c IRD abundance: IRD grains per gram (red) and IRD percent [(IRD grains/(IRD grains + planktonic foraminifera) $\times 100)]$ (ref. ${ }^{33}$ ). d Bulk carbonate $\delta^{18} \mathrm{O}$ (ref. $\left.{ }^{35}\right)$. e Planktonic (G. bulloides) foraminiferal $\delta^{18} \mathrm{O}$ (ref. ${ }^{33}$ ). Vertical bars denote HS4, HS5 and HS5a. Triangles denote depths from which detrital carbonate grains were taken for stable isotope measurements (See Fig. 3 ).

(Fig. 1f and e) reproduce the typical succession of stadials and interstadials from DO15 to DO7. Most extreme changes were associated with HS5 and HS4, leading to $\sim 4{ }^{\circ} \mathrm{C}$ decreases in SST and $\sim 1 \%$ increases in planktonic $\delta^{18} \mathrm{O}$. Benthic foraminiferal $\delta^{18} \mathrm{O}$ values (Fig. $1 \mathrm{~g}$ ) decrease gradually during stadials, with greater reductions $(\sim 0.5 \%)$ during HS5 and HS4. A distinct peak in IRD abundance occurs within HS4 and a much smaller peak in HS5; most commonly found lithics are quartz, with presence of some detrital carbonate grains (Figs. 1d and 2c). The bulk carbonate $\delta^{18} \mathrm{O}$ record (Fig. $2 \mathrm{~d}$ ), a sensitive proxy for identifying Heinrich layers, shows that the IRD peaks at $\sim 10$ and $\sim 12 \mathrm{~m}$ in MD01-2444 are marked by the lowest values, in line with low $\delta^{18} \mathrm{O}$ values of dolomitic limestone in northeastern Canada ${ }^{36}$. Stable isotope analyses on single detrital carbonate grains taken from these IRD peaks reveal that their $\delta^{18} \mathrm{O}$ and $\delta^{13} \mathrm{C}$ composition is consistent with an origin from Hudson Strait ${ }^{36}$ (Fig. 3). The X-ray fluorescence (XRF) $\mathrm{Zr} / \mathrm{Sr}$ ratio (Fig. 1a), which is the inverse of $\mathrm{Ca} / \mathrm{Ti}$ (Fig. 2a), has high values during stadials. The ratios reflect variations in the relative proportion of detrital $(\mathrm{Zr}$, $\mathrm{Ti})$ and biogenic $(\mathrm{Sr}, \mathrm{Ca}$ ) sediment supply, which is controlled by both carbonate production and dilution by terrigenous sediment ${ }^{35}$. During stadials, carbonate productivity decreased relative to the terrigenous supply, with contributions of material from the Tagus river drainage basin ${ }^{37}$, and also from lateral transport, as a result of the deepening and intensification of Mediterranean Outflow Water 38,39 . Input of IRD contributed secondarily to terrigenous sediment during HS4, but very little during HS5.

Coincident with the IRD peaks, the abundance of the polar foraminifer Neogloboquadrina pachyderma reaches a maximum in HS5 and especially HS4 (Fig. 1d). The pollen record also shows contractions (expansions) of temperate tree populations (Fig. 1b) during stadials (interstadials), reflecting changes in moisture
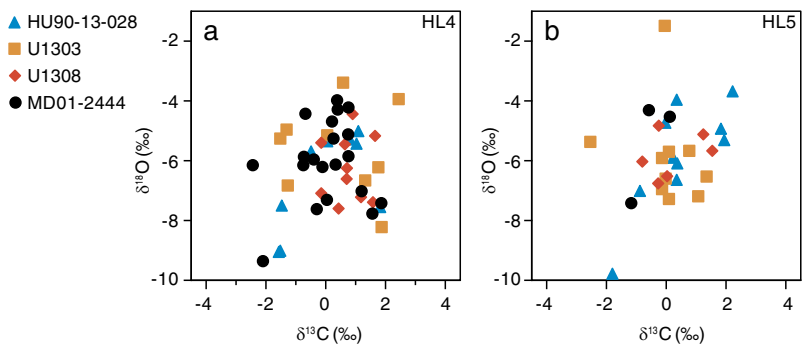

Fig. 3 Isotopic composition of carbonate grains from Heinrich layers HL4 and HL5. a $\delta^{18} \mathrm{O}$ and $\delta^{13} \mathrm{C}$ measured on single detrital carbonate grains from depths $10.06 \mathrm{~m}$ (HL4) in core MD01-2444 (circles) (this study) compared to the $\delta^{18} \mathrm{O}$ and $\delta^{13} \mathrm{C}$ composition of detrital carbonate grains ${ }^{36}$ from HL4 in cores HU90-13-028 (triangles), U1303 (squares) and U1308 (diamonds) in the North Atlantic. $\mathbf{b} \delta^{18} \mathrm{O}$ and $\delta^{13} \mathrm{C}$ measured on single detrital carbonate grains from depth $11.98 \mathrm{~m}$ (HL5) in core MD01-2444 (circles) (this study) compared to the $\delta^{18} \mathrm{O}$ and $\delta^{13} \mathrm{C}$ composition of detrital carbonate grains ${ }^{36}$ from HL5 in cores HU90-13-028 (triangles), U1303 (squares) and U1308 (diamonds) in the North Atlantic.

availability and temperature; semi-desert taxa (Artemisia, Chenopodiaceae/Amaranthaceae) (Fig. 1c) show the largest increases in HS5 and HS4. Following the initial expansion of tree populations, a minor reversal is observed during the early part of interstadials 12 and DO 8 (Fig. 1b), that does not have any counterpart in the palaeoceanographic proxies.

Western Iberian climate variability in the context of wider MIS 3 changes. As reported from the Portuguese Margin ${ }^{30}$, MIS 3 changes in planktonic $\delta^{18} \mathrm{O}$ closely map onto those of the Greenland NGRIP $\delta^{18} \mathrm{O}_{\text {ice }}$ record ${ }^{40}$ (Fig. 4b). This has previously formed the basis of the MD01-2444 age model, whereby abrupt transitions in planktonic $\delta^{18} \mathrm{O}$ were aligned to those of the Greenland $\delta^{18} \mathrm{O}_{\text {ice }}$ record ${ }^{33}$. Here, we retain the same principle for our age model, but use the modified WD2014 timescale ${ }^{41}$ ("Methods" and Supplementary Fig. 1). The benthic $\delta^{18} \mathrm{O}$ record resembles the West Antarctic Ice Sheet Divide ice-core $\delta^{18} \mathrm{O}_{\text {ice }}$ record $^{42}$ (Fig. 4a), both in its shape and phasing relative to Greenland and North Atlantic surface temperature records, reflecting changes in local deep-water $\delta^{18} \mathrm{O}$, a significant portion of which may be due to changes in deep-water sourcing and/or source signature ${ }^{43}$. Accordingly, the asynchronous phasing between the planktonic and benthic $\delta^{18} \mathrm{O}$ has been interpreted as a fingerprint of ocean circulation changes associated with interhemispheric heat transport and the bipolar-seesaw ${ }^{32}$.

Comparison of the temperate tree pollen record with the Hulu speleothem record ${ }^{44}$ from SE China (Fig. 4e) reveals a close similarity, suggesting coherent changes in the hydrological cycle. This is in line with a body of evidence from palaeorecords and climate modelling studies showing changes in hydroclimate across southern Eurasia associated with variations in AMOC strength, SST and latitudinal shifts in the ITCZ ${ }^{12,16,21,22}$. It is interesting to note that, as in the MD01-2444 pollen record, a minor reversal within the early part of interstadials 12 and DO 8 is observed in the Hulu $\delta^{18} \mathrm{O}$ record ${ }^{44}$ as well as the $\delta^{18} \mathrm{O}$ and $\delta^{13} \mathrm{C}$ speleothem records from Sofular Cave ${ }^{12}$ in Turkey. It is unclear whether these represent isolated local events or complex trends of precipitation increase across low-to-mid latitudes.

Variations in SST and shifts in the ITCZ with attendant changes in mid- and low-latitude hydroclimate and tropical wetland extent can also account for the good correspondence between changes in western Iberian vegetation and atmospheric $\mathrm{CH}_{4}$ concentrations ${ }^{17}$ (Fig. 4d). Interstadial expansions of tree populations are coherent with increases in $\mathrm{CH}_{4}$ concentrations, although the amplitude of the 


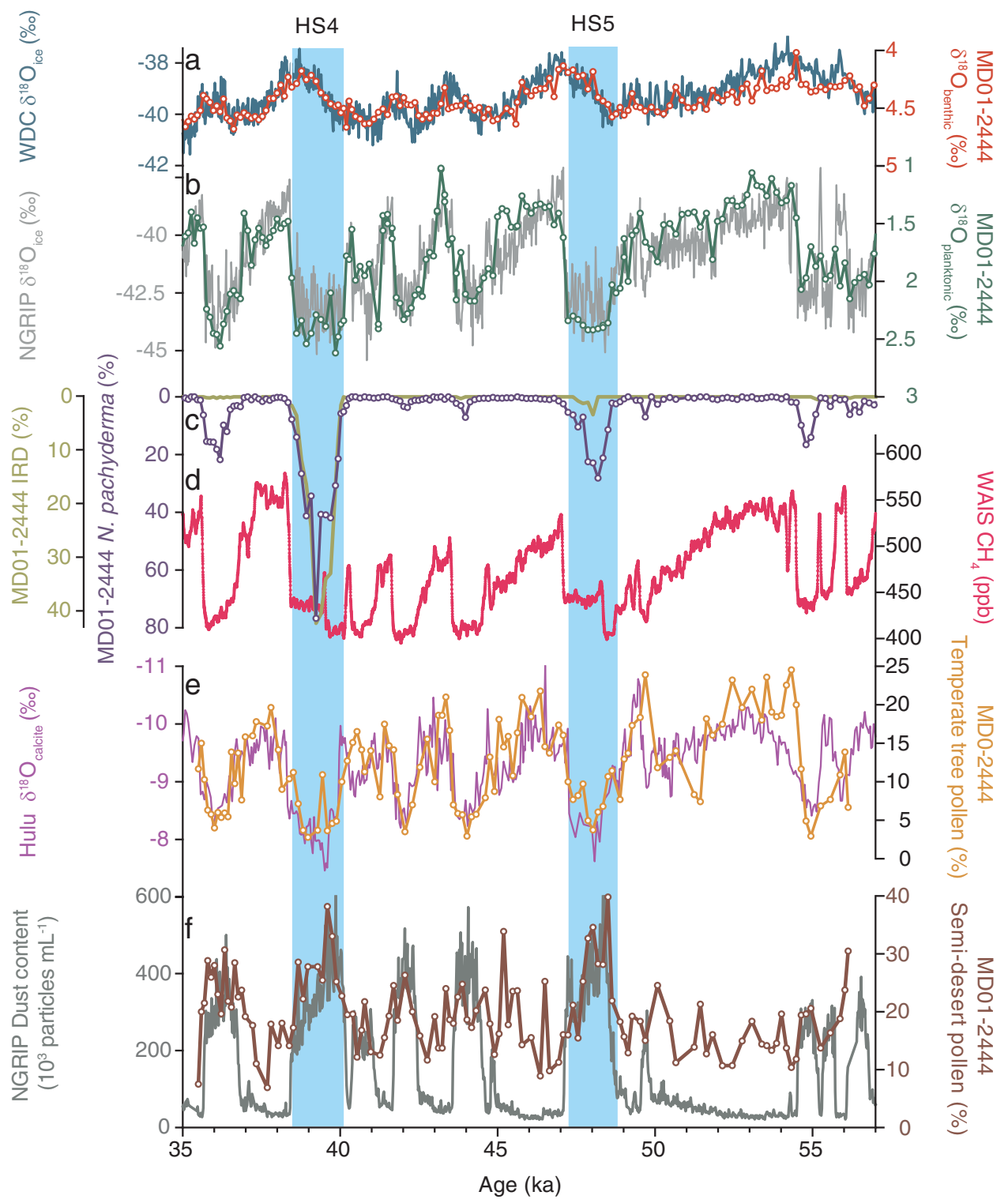

Fig. 4 Comparison of MIS 3 paleoclimate records. a West Antarctic Ice Sheet Divide ice-core (WDC) $\delta^{18} \mathrm{O}_{\text {ice }}\left(\right.$ ref. $\left.{ }^{42}\right)$ and $M D 01-2444 \delta^{18} \mathrm{O}_{\text {benthic }}$. b NGRIP ice-core $\delta^{18} \mathrm{O}_{\text {ice }}$ (ref. ${ }^{40}$ ) and MD01-2444 $\delta^{18} \mathrm{O}_{\text {planktonic. }}$ c MD01-2444 percent IRD and N. pachyderma (inverse Y-scales). d Atmospheric methane concentration in WDC (ref. ${ }^{17}$ ). e Hulu speleothem $\delta^{18} \mathrm{O}_{\text {calcite }}$ (ref. ${ }^{44}$ ) and MD01-2444 temperate tree pollen percentages. $\mathbf{f}$ NGRIP dust content ${ }^{45}$ and MD01-2444 semi-desert (Artemisia and Chenopodiaceae/Amaranthaceae) pollen percentages. All records are plotted on WD2014 timescale ${ }^{41}$, except Hulu, which is on its own U/Th chronology 44 . Vertical bars denote HS4 and HS5.

changes is not always similar. Decreases in $\mathrm{CH}_{4}$ concentration at the start of stadials are paralleled by contractions of temperate tree populations and increases in semi-desert taxa. The highest pollen values of semi-desert taxa occur during the first half of HS5 and HS4 and appear coeval with peaks in dust content (considered to originate from east Asian deserts) in the NGRIP ice-core ${ }^{45}$, pointing to increased aridity across Eurasia (Fig. 4f). The shifts towards higher $\mathrm{CH}_{4}$ concentrations partway through HS5 and HS4 are temporally close to peaks in IRD and minimum SST in MD012444. Given the great distance from Hudson Strait to the Portuguese Margin, it is remarkable that icebergs could travel that far without melting during HS4 and HS5. Sea-ice in the North Atlantic must have been at its maximum extent at these times to permit trans-Atlantic transport ${ }^{46}$. This in turn could have led to the most southerly displacements of the ITCZ, which may account for the excess $\mathrm{CH}_{4}$ production from Southern Hemisphere wetlands, as suggested in ref. ${ }^{17}$.

Anatomy of HS5 and HS4. While non-Heinrich stadials appear as relatively brief intervals of uniform cooling, HS5 and HS4 contain considerable structure. We therefore focus on the sequence of changes in different proxies during these intervals within MD012444 (Fig. 5). While the absolute ages depend on the alignment to the Greenland ice-core record, the relative phasing of our proxies within the same sediment sequence is independent of the age model. We demarcate the onset and end of HS5 and HS4 by using the mid-point of the most abrupt transitions in planktonic $\delta^{18} \mathrm{O}$, which may reflect rapid temperature changes in the optimum habitat of G. bulloides. Similar boundaries emerge when we employ the statistical tools Rampfit/Breakfit to obtain an objective 


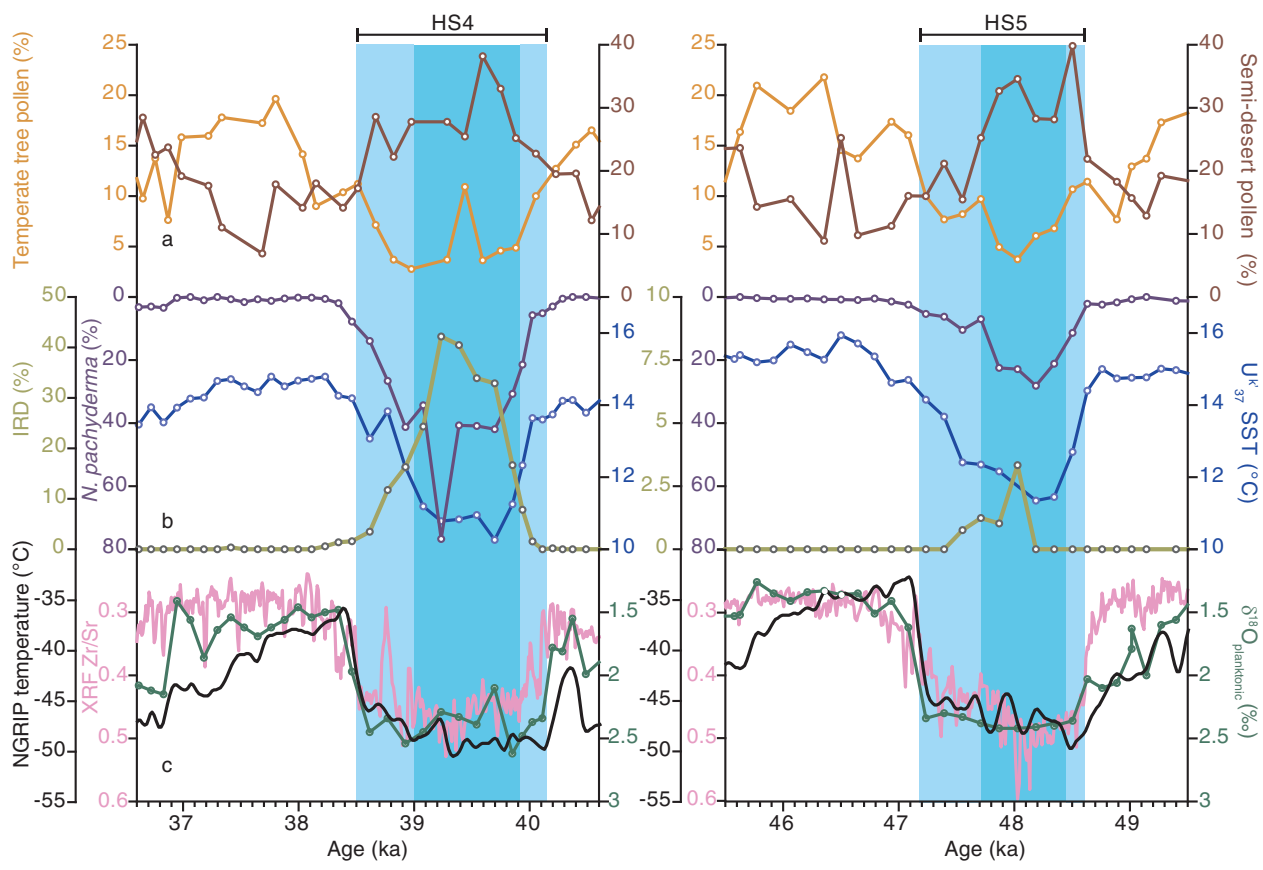

Fig. 5 MD01-2444 records across the intervals 36.6-40.6 ka and 45.5-49.5 ka. a Temperate (Mediterranean + Eurosiberian) tree and semi-desert (Artemisia and Chenopodiaceae/Amaranthaceae) pollen percentages (note different scales). b Percent ice-rafted detritus (IRD) (note different scales in HS4 and HS5), N. pachyderma (inverse scale) and alkenone-based Uk' ${ }_{37}$ SST. (c), XRF Zr/Sr ratio and planktonic (G. bulloides) foraminiferal $\delta^{18} \mathrm{O}$. Also shown is the temperature reconstruction from the NGRIP ice-core ${ }^{49}$. All records are plotted on the WD2014 timescale ${ }^{41}$. Vertical blue bars denote HS4 and HS5; light blue bars denote the initial cooling and final warming phases, while dark blue bars denote the phases of maximum cooling (see text).

determination of the abrupt transition mid-points in the planktonic $\delta^{18} \mathrm{O}$ and the XRF $\mathrm{Zr} / \mathrm{Sr}$ data ("Methods" and Supplementary Table 1). Overall, the proxies show a relatively fast cooling phase (200-300 years [Supplementary Table 2]) at the start of the stadials, leading to an interval ( $750-900$ years) characterized by maximum IRD and $N$. pachyderma values, minimum alkenone SST and maximum semi-desert pollen percentages, representing the most extreme impact of the iceberg discharge. This is followed by a 500-800-year interval (Supplementary Table 2) of slowly evolving conditions with superimposed oscillations towards more biogenic sediments, reduced IRD and N. pachyderma abundances, higher alkenone SST, increasing temperate tree populations. The presence of these gradual changes alongside the more abrupt shifts in planktonic $\delta^{18} \mathrm{O}$ and high sediment accumulation rates $(20-24 \mathrm{~cm}$ $\mathrm{kyr}^{-1}$ ) suggest that these features are not artefacts of bioturbation. In addition, $N$. pachyderma abundance mirrors the gradual changes in alkenone SST, despite belonging to different size fractions, which suggests that particle-size induced differential bioturbation ${ }^{39}$ is not significant.

A complex HS4 has also been observed in indicators of lowlatitude climate in ice-cores and Brazilian speleothems, with more extreme conditions occurring near the middle of the stadial and considered to represent the southernmost migration of the ITCZ $^{47,48}$. Of particular interest is the gradual evolution towards interstadial conditions in western Iberian SST and precipitation following peak iceberg discharge, in line with Greenland ice-core ${ }^{17} \mathrm{O}$-excess and Brazilian speleothem evidence indicating a slow recovery of Northern Hemisphere low-latitude precipitation associated with a gradual northward shift in the ITCZ ${ }^{47,48}$. This differs from atmospheric $\mathrm{CH}_{4}$ concentrations (Fig. 4d), which resemble a square-wave, with a rapid increase in the middle of HS5 and HS4, followed by quasi-stable values until the next abrupt shift at the onset of the interstadial ${ }^{17}$. Given that atmospheric $\mathrm{CH}_{4}$ is a globally integrated signal, it is possible that the quasi-stable values during a period that the ITCZ is inferred to have shifted gradually northward represent a balance between the deactivation and activation of different sources in the Southern and Northern Hemispheres ${ }^{48}$. Small warming trends $\left(2.5^{\circ} \mathrm{C}\right.$ from 47.8 to $47.3 \mathrm{ka}$; $3{ }^{\circ} \mathrm{C}$ from 39 to $38.6 \mathrm{ka}$ ) are also observed in reconstructed temperatures from the NGRIP ice-core ${ }^{49}$, but are then followed by the abrupt DO warming events $\left(\sim 10-12^{\circ} \mathrm{C}\right)$ (Fig. $5 \mathrm{c}$ ).

Climate model experiment. To explore the rate and phasing of changes occurring during the transition towards interstadial conditions as AMOC begins to recover, we perform a meltwater experiment with the Earth System model of intermediate complexity, LOVECLIM, forced with appropriate MIS 3 boundary conditions ("Methods").

From $40 \mathrm{ka}$, a triangular meltwater pulse with a maximum amplitude of $0.2 \mathrm{~Sv}$ reached after 400 years and decreasing thereafter for 400 years is added to the North Atlantic between $50^{\circ} \mathrm{N}$ and $60^{\circ} \mathrm{N}$ (Fig. 6a). This weakens the AMOC, leading to seaice advance in the Nordic Seas and the northern North Atlantic, and a $5.4^{\circ} \mathrm{C}$ cooling over Greenland (Fig. 6b-e). The reduced meridional heat transport to the North Atlantic induces a $3{ }^{\circ} \mathrm{C}$ SST decrease at the Portuguese Margin and a $20 \%$ reduction in precipitation over western Iberia (Fig. $6 \mathrm{f}-\mathrm{g}$ ), while the ITCZ shifts to the south (Supplementary Fig. 2). To allow the AMOC to recover on its own, the Bering Strait is opened at model year 600 $(39.40 \mathrm{ka})$. The opening of the Bering Strait leads to a reduction of the low salinity anomaly in the North Atlantic due to increased mixing with North Pacific waters, thus slowly reinstating deepocean convection south of the Norwegian Sea between model years 600 and 1080 (39.40 and $38.92 \mathrm{ka})$ and strengthening the transport of salty and warm tropical waters to the Northeast Atlantic. No significant changes in Greenland temperature are simulated during that time, while SST off the Portuguese Margin gradually increase by $\sim 1^{\circ} \mathrm{C}$ (Supplementary Table 3; Figs. 6c,f and $7 \mathrm{a})$. Once deep convection reaches the Norwegian Sea, the AMOC increases from 10 to $27 \mathrm{~Sv}$ over 220 years (model years 


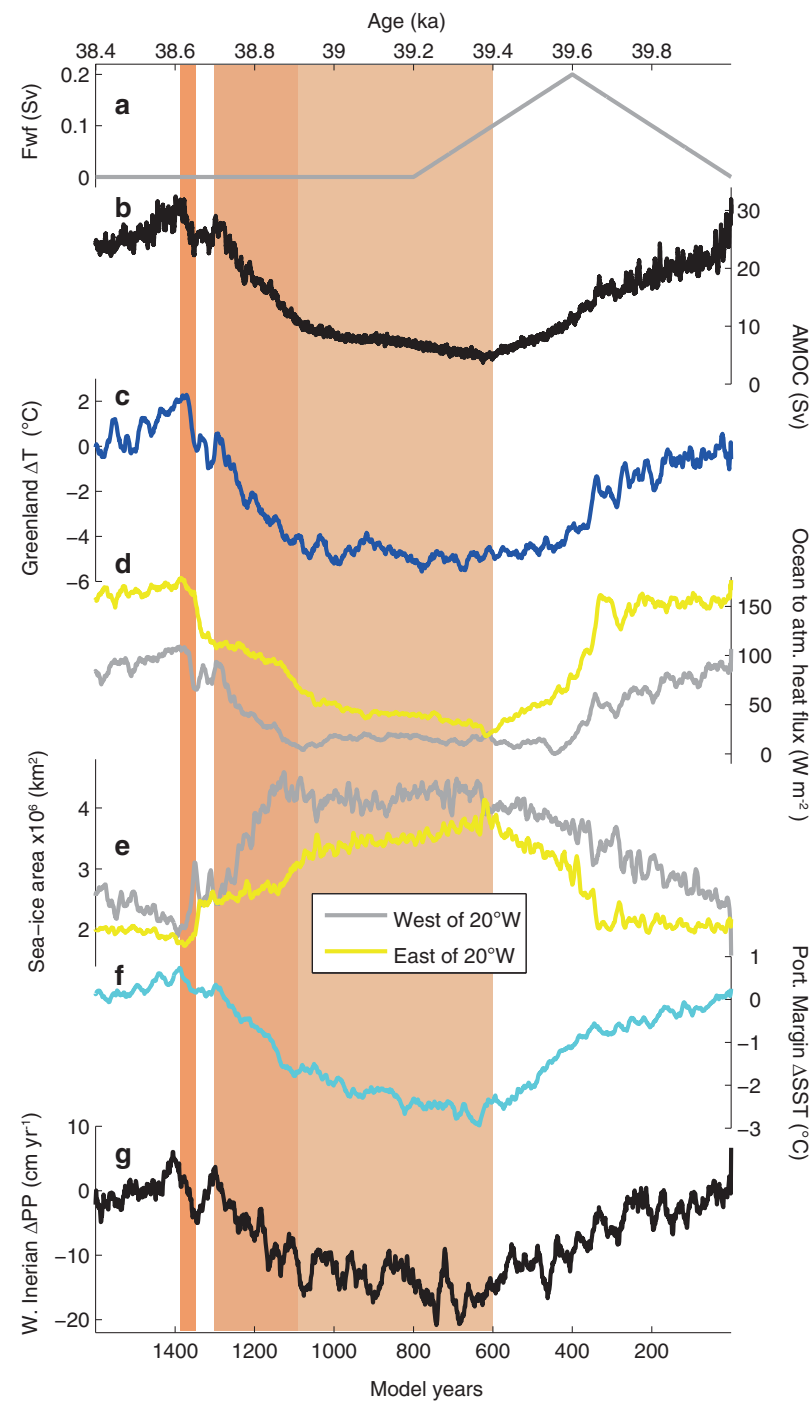

Fig. 6 Timeseries of the numerical experiment of HS4 performed with the Earth system model of intermediate complexity LOVECLIM. a Freshwater input (Sv). b monthly AMOC (Sv) with a 21 month-smoothing. c Annual mean Greenland air temperature anomalies $\left({ }^{\circ} \mathrm{C}\right)$. d Ocean to atmosphere heat flux $\left(\mathrm{W} \mathrm{m}^{-2}\right)$ averaged over $42^{\circ} \mathrm{W}-20^{\circ} \mathrm{W}, 60^{\circ} \mathrm{N}-75^{\circ} \mathrm{N}$, and the east of the Nordic Seas $20^{\circ} \mathrm{W}-20^{\circ} \mathrm{E}, 60^{\circ} \mathrm{N}-80^{\circ} \mathrm{N}$. e The annual mean sea-ice area integrated over the Northwest Atlantic $\left(70^{\circ} \mathrm{W}-20^{\circ} \mathrm{W}, 40^{\circ} \mathrm{N}-90^{\circ} \mathrm{N}\right)$ and the Northeast Atlantic/Nordic Seas $\left(20^{\circ} \mathrm{W}-40^{\circ} \mathrm{E}, 40^{\circ} \mathrm{N}-90^{\circ} \mathrm{N}\right)\left(\times 10^{6}\right.$ $\left.\mathrm{km}^{2}\right)$. f Portuguese Margin SST $\left({ }^{\circ} \mathrm{C}, 15^{\circ} \mathrm{W}-8^{\circ} \mathrm{W}, 37^{\circ} \mathrm{N}-43^{\circ} \mathrm{N}\right) . \mathbf{g}$

Precipitation over western Iberia $\left(\mathrm{cm} \mathrm{yr}^{-1}, 10^{\circ} \mathrm{W}-5^{\circ} \mathrm{W}, 36^{\circ} \mathrm{N}-43^{\circ} \mathrm{N}\right)$. A $21-$ year smoothing has been applied to the timeseries in $(\mathbf{c}-\mathbf{g})$. Bands refer to the phases discussed in the text and in Supplementary Table 3.

1080 to $1300 ; 38.92$ to $38.70 \mathrm{ka}$ ), the annual mean sea-ice area in the eastern side of the Nordic Seas gradually decreases by $17 \%$, and Greenland temperature increases by $4.6^{\circ} \mathrm{C}$ (Fig. $6 \mathrm{~b}-\mathrm{d}$ ). This is also associated with a $2{ }^{\circ} \mathrm{C}$ increase in SST on the Portuguese Margin. As temperature increases over the North Atlantic, the ITCZ shifts northward, back to its original position at $40 \mathrm{ka}$ (Supplementary Fig. 2). Higher North Atlantic SST and a northward ITCZ shift lead to an increase in precipitation in western Iberia and the northern tropics, respectively (Figs. $6 \mathrm{~g}$ and $7 \mathrm{~d}$ ), in agreement with paleo-records ${ }^{16}$. Precipitation over western Iberia displays strong decadal-scale variability (Fig. 6g). An AMOC overshoot occurs within 30 years (model years $1350-1380 ; 38.65-38.62 \mathrm{ka}$ ), whereby the AMOC increases by $\sim 6$
Sv, associated with a major loss of sea-ice along the eastern shore of Greenland as well as in the Nordic Seas between $\sim 68^{\circ} \mathrm{N}$ and $78^{\circ}$ $\mathrm{N}$ and a $2.5^{\circ} \mathrm{C}$ increase in Greenland temperature (Fig. $6 \mathrm{c}$ ). This Greenland warming is mostly due to the sea-ice retreat, which coupled with enhanced deep-ocean convection leads to an increase of the ocean-to-atmosphere heat flux of $60 \mathrm{~W} \mathrm{~m}^{-2}$. This last warming phase is particularly visible at high latitudes, but still induces a further $0.5^{\circ} \mathrm{C}$ SST increase on the Portuguese Margin, and enhanced precipitation over the Iberian peninsula and the northern tropics above their $40 \mathrm{ka}$ level (Fig. 7e, f).

The experiment, therefore, simulates an initial slow warming in Greenland in HS4 and then a more abrupt warming, with temperature increases linearly scaling with the extent of sea-ice cover (Supplementary Fig. 3c), in line with previous studies suggesting that changes in sea-ice and associated ocean-to-atmosphere heat flux directly influence Greenland temperature $^{25}$. The modelled SST rise on the Portuguese Margin also linearly scales with the AMOC changes (Supplementary Fig. 3b) in agreement with the gradual SST increase observed in the MD01-2444 alkenone record. However, the simulation suggests an overall temperature increase of $\sim 7.1^{\circ} \mathrm{C}$ in Greenland in 300 years, whereas ice-core records suggest that the abrupt DO 8 warming was at least $10^{\circ} \mathrm{C}$ and took less than a hundred years $^{3,49}$. If the AMOC recovery is induced by a negative freshwater input instead (Supplementary Methods and Notes), then the main temperature increase over Greenland $\left(7.9^{\circ} \mathrm{C}\right)$ occurs in 150 years instead of 300 years (Supplementary Fig. S4). Thus, both experiments show a centennial-scale gradual AMOC recovery, with the negative freshwater forcing inducing a relatively faster AMOC reinvigoration and a more abrupt warming in Greenland in the final stages. However, both experiments still underestimate the full amplitude and rate of warming in Greenland. The simulated Greenland temperature changes are highly dependent on the rate and amplitude of AMOC change, the location of deep-ocean convection, and the northern North Atlantic/Nordic Seas sea-ice cover. Given the close link between changes in sea-ice cover around Greenland and Greenland temperature ${ }^{21,50}$, this suggests that the present experiments most likely underestimate the stadial-interstadial changes in sea-ice cover. In addition, proxy records from the Nordic Seas highlight a significant sub-surface warming during stadials $^{51-53}$, which may be underestimated in our simulations.

\section{Discussion}

Our Portuguese Margin records link millennial-scale variability in the high-latitude North Atlantic with lower-latitude hydroclimate changes and reveal that Greenland ice-core temperature records do not provide a unique template for the patterns and rates of warming observed at different locations. The similarity in the trajectory of changes following the maximum HS cooling between our data and modelling results suggests that a multi-centennial AMOC recovery and associated increased oceanic heat transport to the North Atlantic led to a gradual SST increase and a shift to wetter conditions over western Iberia. The AMOC recovery could be due to enhanced advection of salty low-latitude surface waters (a result of reduced precipitation as the ITCZ shifted southwards) to the North Atlantic ${ }^{54}$, potentially amplified by increased atmospheric $\mathrm{CO}_{2}$ concentration ${ }^{28}$, or by an increase in the height of the Laurentide ice-sheet ${ }^{27}$. Rapid sea-ice retreat, on the other hand, highlights the important role of tipping points leading to large changes observed in Greenland air temperatures within a few decades. Instead of one dominant mechanism, what emerges is a combination of interacting processes that include both fast and slow components of the coupled atmosphere-ocean-sea-ice 


\section{SST anomalies and $15 \%$ sea-ice contours}
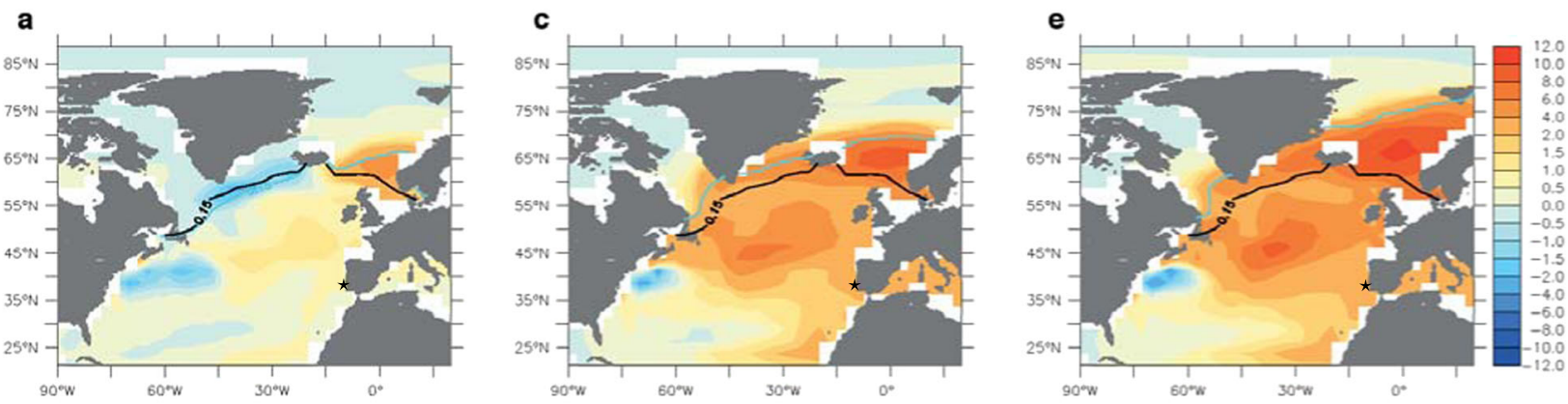

\section{Precipitation anomalies}
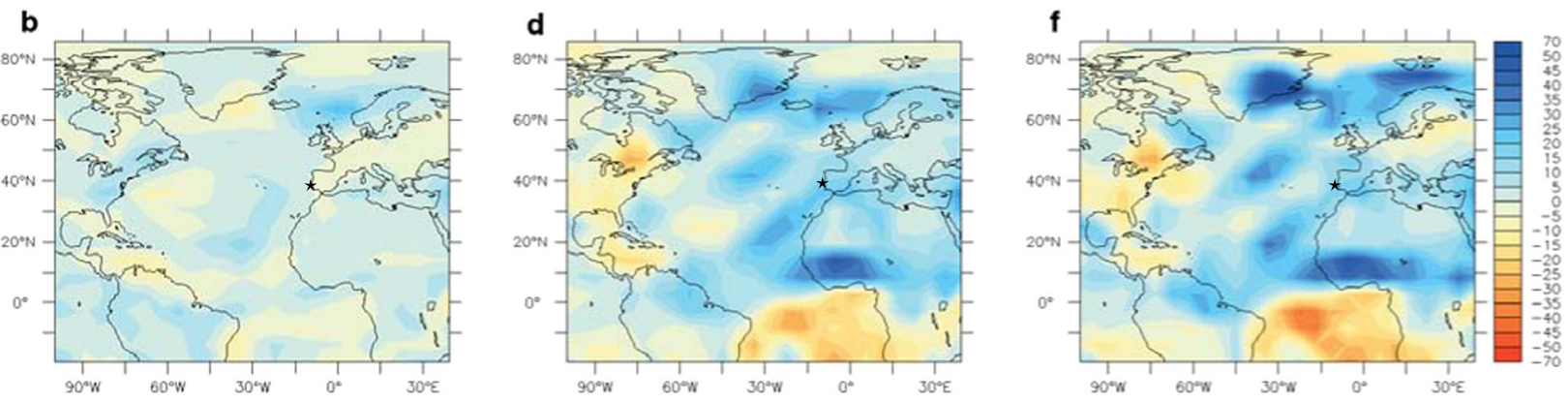

Fig. 7 Maps of annual mean SST and precipitation anomalies from full stadial conditions for three HS4 recovery phases in the LOVECLIM experiment. a SST anomalies $\left({ }^{\circ} \mathrm{C}\right.$ ) and $15 \%$ sea-ice contour (full stadial in black, recovery in light blue) for 38.90-38.92 ka (model years 1060-1080) compared to full stadial conditions 39.40-39.42 ka (model years 600-620). b Precipitation anomalies (cm yr ${ }^{-1}$ ) for 38.90-38.92 ka (model years 1060-1080) compared to full stadial conditions $39.40-39.42 \mathrm{ka}$ (model years 600-620). c SST anomalies $\left({ }^{\circ} \mathrm{C}\right.$ ) and $15 \%$ sea-ice contour (full stadial in black, recovery in light blue) for 38.70-38.72 ka (model years 1300-1320) compared to full stadial conditions 39.40-39.42 ka (model years 600-620). d Precipitation anomalies (cm $\mathrm{yr}^{-1}$ ) for 38.70-38.72 ka (model years 1300-1320) compared to full stadial conditions 39.40-39.42 ka (model years 600-620). e SST anomalies ( ${ }^{\circ} \mathrm{C}$ ) and $15 \%$ sea-ice contour (full stadial in black, recovery in light blue) for 38.61-38.62 ka (model years 1370-1380) compared to full stadial conditions 39.40-39.42 ka (model years 600-620). f Precipitation anomalies ( $\mathrm{cm} \mathrm{yr}^{-1}$ ) for 38.61-38.62 ka (model years 1370-1380) compared to full stadial conditions 39.40-39.42 ka (model years 600-620). Star denotes location of core MD01-2444 on the Portuguese Margin.

system and accommodate a diversity of changes on a range of timescales.

\section{Methods}

Core location and study interval. Core MD01-2444 $\left(37^{\circ} 33.68^{\prime} \mathrm{N}\right.$; $10^{\circ} 08.53^{\prime} \mathrm{W}$; $2637 \mathrm{~m}$ water depth; $27.45 \mathrm{~m}$ in length) was recovered in 2001, using the CALYPSO Giant Piston corer aboard the French research vessel Marion Dufresne II. This study focuses on the 9-13.67 m section in MD01-2444 ( 35-57 ka).

Stable isotope analyses. Measurements of foraminiferal stable isotopes were carried out in the Godwin Laboratory for Palaeoclimate Research (University of Cambridge), using VG PRISM and VG SIRA mass spectrometers. On both instruments, samples were reacted sequentially using ISOCARB systems. Results are reported with reference to the international standard VPDB and the precision is better than $\pm 0.08 \%$ for $\delta^{18} \mathrm{O}$. For the planktonic isotope record, analyses were made on samples consisting of 30 specimens of G. bulloides in the 300-355 $\mathrm{mm}$ size fraction ${ }^{33}$. The benthic isotope record was generated by the late N.J. Shackleton ${ }^{32}$. Where possible two or three separate analyses of different benthic species were made in each sample; a correction factor was applied according to the species and the average of all the corrected values at each level is shown in the figures. The following species were analysed, and adjusted as indicated: Cibicidoides sp.: +0.51 ; Uvigerina peregrina and similar specimens: 0.0 ; Globobulimina affinis: -0.4 ; Cibicidoides wuellerstorfi, +0.64 ; Globocassidulina sp.: -0.1 ; Hoeglundina elegans: -0.7 . These adjustments are optimized for this particular core in accordance with the long-standing convention by which Uvigerina peregrina is assumed to deposit oxygen in isotopic equilibrium. Results are reported in Supplementary Data 1.

Bulk oxygen isotopes of carbonate were measured using a ThermoFisher GasBench II equipped with a CTC Combi-Pal autosampler and interfaced via continuous flow with a ThermoFisher MAT 253 isotope ratio mass spectrometer (IRMS) $^{35}$. About $200-300 \mathrm{mg}$ of bulk sample was used. Analytical precision is estimated to be $\pm 0.08 \%$ for $\delta^{18} \mathrm{O}$ of an internal standard (Carrara marble). Results are reported in Supplementary Data 1.

Stable isotopes of detrital carbonate were measured on single grains taken from the peaks of HL4 (10.06 m) and HL5 (11.98 m) in MD01-2444. Detrital carbonate grains were picked from the $>150 \mu \mathrm{m}$ fraction and leached in a weak acid. Each detrital carbonate grain was ground and between 20 and $60 \mu \mathrm{g}$ of powdered sample was loaded into Exetainer vials and sealed with silicone rubber septa using a screw cap. The samples were flushed with CP grade helium, then acidified with $104 \%$ orthophosphoric acid, left to react for $1 \mathrm{~h}$ at 70 degrees Celsius and then analysed using a Thermo Gasbench preparation system attached to a Thermo Delta V mass spectrometer in continuous flow mode. Each run of samples was accompanied by 10 reference carbonates (Carrara Z) and 2 control samples (Fletton Clay). Carrara $Z$ has been calibrated to VPDB using the international standard NBS19. The results are reported with reference to the international standard VPDB and the precision is better than \pm 0.08 per mil for $\delta^{13} \mathrm{C}$ and \pm 0.10 per mil for $\delta^{18} \mathrm{O}$. Results are reported in Supplementary Data 1.

Planktonic foraminifera fauna. Identification of N. pachyderma in the greater than $150 \mu \mathrm{m}$ size fraction was carried out on split subsamples containing at least 300 whole specimens ${ }^{33}$. Results are reported in Supplementary Data 1.

Ice-rafted detritus. Lithic counts were undertaken on the same split fraction used for faunal identification ${ }^{33}$. Results are reported in Supplementary Data 1.

Alkenone SST. Sediment samples $(2.5-2.57 \mathrm{~g})$ were freeze-dried and extracted by sonication using dichloromethane. The extracts were dried under nitrogen and hydrolysed with $7 \%$ potassium hydroxide in methanol. Extraction with hexane yielded a fraction enriched in neutral compounds, which was cleaned with ultrapure water. The purified extracts were derivatised with BSTFA. Samples were injected diluted in toluene. They were then analysed with a Varian gas chromatograph Model 3400 equipped with a septum programmable injector and a flame ionisation detector. Absolute concentration errors were below $10 \%$. Reproducibility 
tests showed that the uncertainty in the $\mathrm{Uk}^{\prime}{ }_{37}$ determinations was lower than 0.015 (ca. $\pm 0.5^{\circ} \mathrm{C}$ ). The SST reconstruction $\left(\mathrm{U}^{\mathrm{k}_{3}^{\prime}}{ }_{37}-\mathrm{SST}\right.$ ) was obtained from the relative composition of $\mathrm{C} 37$ unsaturated alkenones [ $\left.\mathrm{U}^{\prime}{ }_{37}=\mathrm{C} 37: 2 /(\mathrm{C} 37: 2+\mathrm{C} 37: 3)\right]$, using the calibration equation $\mathrm{Uk}^{\prime}{ }_{37}=0.033 * \mathrm{SST}+0.044$ (ref. ${ }^{55}$ ). Detailed analytical procedures are described in in ref. ${ }^{34}$. Results are reported in Supplementary Data 1.

Pollen analysis. Sediment samples of $1.5-4 \mathrm{~cm}^{3}$ were prepared for pollen analysis using the standard hot acid digestion technique. Fine sieving, through a mesh of 10 $\mu \mathrm{m}$ or less, was not used as it could result in a loss of pollen. Residues were mounted in silicone oil for microscopic analysis at magnifications of 400, 630 and 1000 times. Nomenclature follows ref. ${ }^{56}$. Abundances are expressed as percentages of the main sum, which includes all pollen except Pinus, Pteridophyte spores and aquatics. Pinus was excluded from the main sum, as it is over-represented in marine sediments ${ }^{57}$. A minimum of 100 pollen grains, excluding Pinus, spores and aquatics, was counted in each sample. Results are reported in Supplementary Data 1.

Pollen studies from continental shelf sequences suggest that transport to these areas is controlled primarily by fluvial and secondarily by aeolian processes ${ }^{58}$. Studies on modern pollen deposition in fluvial systems indicate the rapid incorporation of pollen to marine sediments ${ }^{58}$. On the Portuguese Margin Margin, aeolian pollen transport is limited by the direction of the prevailing offshore winds and pollen is mainly transported to the abyssal site by the sediments carried by the Tagus River ${ }^{59}$. Comparison of modern marine and terrestrial samples along western Iberia has shown that the marine pollen assemblages provide an integrated picture of the regional vegetation of the adjacent continent ${ }^{59}$.

XRF analysis. Archive halves of sections from Core MD01-2444 were analysed using an Avaatech XRF core scanner at the University of Cambridge ${ }^{35}$. The core surface was carefully scraped cleaned and covered with a 4-mm thin SPEXCertiPrep Ultralene foil to avoid contamination and minimize desiccation. Each section was measured using a current of $0.2 \mathrm{~mA}$ at three different voltages: $10,30 \mathrm{kV}$ using a thin lead filter, and $50 \mathrm{kV}$ using a copper filter. XRF data were collected every 2.5 $\mathrm{mm}$. The length and width of the irradiated surface was 2.5 and $12 \mathrm{~mm}$, respectively, with a count time of $40 \mathrm{~s}$. Results are reported in Supplementary Data 1.

Carbonate content. Bulk sediment was acidified with $10 \%$ phosphoric acid using an AutoMateFX carbonate preparation system and evolved $\mathrm{CO}_{2}$ was measured using a UIC (Coulometrics) $5011 \mathrm{CO}_{2}$ coulometer. Analytical precision is estimated to be $\pm 1 \%$ by repeated measurement of a carbonate standard ${ }^{35}$. Results are reported in Supplementary Data 1.

Age model. Following refs. ${ }^{30}$ and ${ }^{33}$, the age model was developed by aligning the abrupt transitions of $\delta^{18} \mathrm{O}$ record of G. bulloides in core MD01-2444 to warming and cooling events in the NGRIP $\delta^{18} \mathrm{O}_{\text {ice }}$ record ${ }^{40}$, here placed on the modified WD2014 timescale ${ }^{41}$

Statistical analyses. To infer objectively the timing of the changes across HS4 and HS5 observed in the $\delta^{18} \mathrm{O}_{\text {planktonic }}$ and XRF $\mathrm{Zr} / \mathrm{Sr}$ records, we use two statistical tools, Rampfit ${ }^{60}$ and Breakfit ${ }^{61}$. Rampfit is based on the simple assumption that shifts observed in the tracers can be characterized as a ramp, i.e., a linear change from one stable state to the other, or in other words, a continuous function, segmented in three parts, linearly connected between the transition end and start points, $\mathrm{T} 1$ and $\mathrm{T} 2$. Hence, only time intervals where the timeseries shaped like a ramp are suitable for the use of this tool, e.g., the timing of the end of HS4 and HS5 in the $\delta^{18} \mathrm{O}_{\text {planktonic }}$ record and the timing of both the onset and end of HS4 and HS5 in the $\mathrm{Zr} / \mathrm{Sr}$ record. To define the onset of HS4 and HS5 in $\delta^{18} \mathrm{O}_{\text {planktonic }}$ record we use the Breakfit tool. Breakfit also uses a continuous function, but it consists of two linear parts connected at a specific point, T2 which represents the point where the slope of the data series changes. Both methods are based on (1) weighted least-squares regression to determine within a prescribed search time interval the ramp location with Rampfit and the break location with Breakfit and (2) a bootstrap simulation to estimate the uncertainty attached to the results.

Numerical experiment. A numerical experiment of HS4 was performed with the Earth system model of intermediate complexity, LOVECLIM. LOVECLIM includes an ocean general circulation model $\left(3^{\circ} \times 3^{\circ}\right.$, and 20 vertical levels), a dynamicthermodynamic sea-ice model, coupled to a quasi-geostrophic T21 atmospheric model, and a dynamic vegetation model ${ }^{62}$. The model was forced with appropriate MIS 3 boundary conditions: orbital parameters ${ }^{63}$, Northern Hemispheric ice-sheet geometry and albedo ${ }^{64}$, and a constant atmospheric $\mathrm{CO}_{2}$ concentration of 195 $\mathrm{ppm}^{65}$. The global salinity is $1 \mathrm{psu}$ larger than during pre-industrial conditions. The initial conditions at $40 \mathrm{ka}$ are taken from ref. ${ }^{22}$. From $40 \mathrm{ka}$, a triangular meltwater pulse with a maximum amplitude of $0.2 \mathrm{~Sv}$ reached after 400 years and decreasing thereafter for 400 years is added into the North Atlantic between $50^{\circ} \mathrm{N}$ and $60^{\circ} \mathrm{N}$. Given the global sea-level at the time of MIS 3 (ref. ${ }^{66}$ ) and the possible sea-level increase during HS4 (ref. ${ }^{67}$ ), the Bering strait is opened at year 39.4 ka to allow for the AMOC to recover.

\section{Data availability}

All data generated for this study are available in Supplementary materials and also from PANGAEA data publisher (https://doi.pangaea.de/10.1594/PANGAEA.919846). They are also available in the British Oceanographic Data Centre repository, where they are archived with the accession code: UCL200122 and can be requested by contacting BODC enquiries, see: https://www.bodc.ac.uk/about/contact_us/contact_details/. Results of the modelling experiment are available at: https://doi.org/10.26190/5ee170029cf6e.

Received: 14 March 2020; Accepted: 18 June 2020; Published online: 13 August 2020

\section{References}

1. Dansgaard, W. et al. Evidence for general instability of past climate from a 250 kyr ice-core record. Nature 364, 218-220 (1993).

2. Bond, G. et al. Correlations between climate records from North Atlantic sediments and Greenland ice. Nature 365, 143-147 (1993).

3. Wolff, E. W., Chappellaz, J., Blunier, T., Rasmussen, S. O. \& Svensson, A. Millennial-scale variability during the last glacial: the ice core record. Quat. Sci. Rev. 29, 2828-2838 (2010).

4. Bond, G. et al. Evidence for massive discharges of icebergs into the North Atlantic Ocean during the last glacial period. Nature 360, 245-249 (1992).

5. Rashid, H., Hesse, R. \& Piper, D. J. W. Evidence for an additional Heinrich event between H5 and H6 in the Labrador Sea. Paleoceanography 18, PA1077 (2003).

6. Hemming, S. Heinrich Events: massive late Pleistocene detritus layer of the north Atlantic and their global climate imprint. Rev. Geophys. 42, RG1005 (2004).

7. Barker, S. et al. Interhemispheric Atlantic seesaw response during the last deglaciation. Nature 457, 1097-1102 (2009).

8. Hodell, D. A. et al. Anatomy of Heinrich Layer 1 and its role in the last deglaciation. Paleoceanography 32, 284-303 (2017).

9. Henry, L. G. et al. North Atlantic Ocean circulation and abrupt climate change during the last glaciation. Science 353, 470-474 (2016).

10. Wang, Y. J. et al. A high-resolution absolute-dated Late Pleistocene monsoon record from Hulu Cave, China. Science 294, 2345-2348 (2001).

11. Genty, D. et al. Precise dating of Dansgaard-Oeschger climate oscillations in western Europe from stalagmite data. Nature 421, 833-837 (2003).

12. Fleitmann, D. et al. Timing and climatic impact of Greenland interstadials recorded in stalagmites from northern Turkey. Geophys. Res. Lett. 36, L19707 (2009).

13. Fletcher, W. J. et al. Millennial-scale variability during the last glacial in vegetation records from Europe. Quat. Sci. Rev. 29, 2839-2864 (2010).

14. Brook, E. J., Sowers, T. \& Orchardo, J. Rapid variations in atmospheric methane concentration during the past 110,000 years. Science 273, 1087-1091 (1996).

15. Wang, X. et al. Interhemispheric anti-phasing of rainfall during the last glacial period. Quat. Sci. Rev. 25, 3391-3403 (2006).

16. Deplazes, G. et al. Links between tropical rainfall and North Atlantic climate during the last glacial period. Nat. Geosci. 6, 213-217 (2013).

17. Rhodes, R. et al. Enhanced tropical methane production in response to iceberg discharge in the North Atlantic. Science 348, 1016-1019 (2015).

18. Broecker, W. S., Petit, D. \& Rind, D. Does the ocean-atmosphere system have more than one stable mode of operation? Nature 315, 21-25 (1985)

19. Manabe, S. \& Stouffer, R. J. Simulation of abrupt climate change induced by freshwater input to the North Atlantic Ocean. Nature 378, 165-167 (1995).

20. Ganopolski, A. \& Rahmstorf, S. Rapid changes of glacial climate simulated in a coupled climate model. Nature 409, 153-158 (2001).

21. Kageyama, M. et al. Climatic impacts of fresh water hosing under Last Glacial Maximum conditions: a multi-model study. Clim. Past 9, 935-953 (2013).

22. Menviel, L., Timmermann, A., Friedrich, T. \& England, M. H. Hindcasting the continuum of Dansgaard-Oeschger variability: mechanisms, patterns and timing. Clim. Past 10, 63-77 (2014).

23. Pedro, J. B. et al. Beyond the bipolar seesaw: Toward a process understanding of interhemispheric coupling. Quat. Sci. Rev. 192, 27-46 (2018).

24. Ziemen, F. A., Kapsch, M.-L., Klockmann, M. \& Mikolajewicz, U. Heinrich events show two-stage climate response in transient glacial simulations. Clim. Past 15, 153-168 (2019).

25. Li, C., Battisti, D. S., Schrag, D. P. \& Tziperman, E. Abrupt climate shifts in Greenland due to displacements of the sea ice edge. Geophys. Res. Lett. 32, L19702 (2005).

26. Li, C. \& Born, A. Coupled atmosphere-ice-ocean dynamics in DansgaardOeschger events. Quat. Sci. Rev. 203, 1-20 (2019).

27. Zhang, X., Lohmann, G., Knorr, G. \& Purcell, C. Abrupt glacial climate shifts controlled by ice sheet changes. Nature 512, 290-294 (2014). 
28. Zhang, X., Knorr, G., Lohmann, G. \& Barker, S. Abrupt North Atlantic circulation changes in response to gradual $\mathrm{CO}_{2}$ forcing in a glacial climate state. Nat. Geosci. 10, 518-524 (2017).

29. Peltier, W. R. \& Vettoretti, G. Dansgaard-Oeschger oscillations predicted in a comprehensive model of glacial climate: a "kicked" salt oscillator in the Atlantic. Geophys. Res. Lett. 41, 7306-7313 (2014).

30. Shackleton, N. J., Hall, M. A. \& Vincent, E. Phase relationships between millennial-scale events 64,000-24,000 years ago. Paleoceanography 15, 565-569 (2000).

31. Sánchez Goñi, M. F., Turon, J.-L., Eynaud, F. \& Gendreau, S. European climatic response to millennial-scale changes in the atmosphere-ocean system during the last glacial period. Quat. Res 54, 394-403 (2000).

32. Margari, V. et al. The nature of millennial-scale climate variability during the past two glacial periods. Nat. Geosci. 3, 127-133 (2010).

33. Vautravers, M. \& Shackleton, N. J. Centennial scale surface hydrology off Portugal during Marine Isotope Stage 3: insights from planktonic foraminiferal fauna variability. Paleoceanography 21, PA3004 (2006).

34. Martrat, B. et al. Four climate cycles of recurring deep and surface water destabilizations on the Iberian margin. Science 317, 502-507 (2007).

35. Hodell, D. et al. Response of Iberian Margin sediments to orbital and suborbital forcing over the past 420 kyr. Paleoceanography 28, 1-15 (2013).

36. Hodell, D. A. \& Curtis, J. H. Oxygen and carbon isotopes of detrital carbonate in North Atlantic Heinrich Events. Mar. Geol 256, 30-35 (2008).

37. Lebreiro, S. M. et al. Sediment instability on the Portuguese continental margin under abrupt glacial climate changes (last 60 kyr). Quaternary Sci. Rev. 28, 3211-3223 (2009).

38. Magill, C. R. et al. Transient hydrodynamic effects infuence organic carbon signatures in marine sediments. Nat. Commun. 9, 4690 (2018)

39. Ausín, B. et al. (In)coherent multiproxy signals in marine sediments: implications for high-resolution paleoclimate reconstruction. Earth Planet. Sci. Lett. 515, 38-46 (2019).

40. NGRIP Ice Core Project Members. High-resolution record of Northern Hemisphere climate extending into the last interglacial period. Nature 431, 147-151 (2004).

41. Buizert, C. et al. The WAIS divide deep ice core WD2014 chronology - Part 1: Methane synchronization (68-31 ka BP) and the gas age-ice age difference. Clim. Past 11, 153-173 (2015).

42. WAIS Divide Project Members. Precise interpolar phasing of abrupt climate change during the last ice age. Nature 520, 661-665 (2015).

43. Skinner, L. C., Elderfield, H. \& Hall, M. in Past and Future Changes of the Ocean's Meridional Overturning Circulation: Mechanisms and Impacts (eds Schmittner, A., Chiang, J. \& Hemming, S. R.) 197-208 (AGU Monograph, 2007).

44. Cheng, $H$. et al. The Asian Monsoon over the past 640,000 years and ice age terminations. Nature 534, 640-646 (2016).

45. Ruth, U. et al. Ice core evidence for a very tight link between North Atlantic and east Asian glacial climate. Geophys. Res. Lett. 34, L03706 (2007).

46. Wagner, T. J. W. et al. Wave inhibition by sea ice enables trans-Atlantic ice rafting of debris during Heinrich events. Earth Planet. Sci. Lett. 495, 157-163 (2018).

47. Guillevic, M. et al. Evidence for a three-phase sequence during Heinrich Stadial 4 using a multiproxy approach based on Greenland ice core records. Clim. Past 10, 2115-2133 (2014).

48. Wendt, K. A. et al. Three-phased Heinrich Stadial 4 recorded in NE Brazil stalagmites. Earth Planet. Sci. Lett. 510, 94-102 (2019).

49. Kindler, P. et al. Temperature Reconstruction from 10 to $120 \mathrm{kyr}$ b2k from the NGRIP ice core. Clim. Past 10, 887-902 (2014).

50. Li, C., Battisti, D. S. \& Bitz, C. M. Can North Atlantic sea ice anomalies account for Dansgaard-Oeschger climate signals? J. Clim 23, 5457-5475 (2010).

51. Rasmussen, T. L. \& Thomsen, E. The role of the North Atlantic Drift in the millennial timescale glacial climate fluctuations. Palaeogeogr., Palaeoclimat., Palaeoecol. 210, 101-116 (2004).

52. Dokken, T. M., Nisancioglu, K. H., Li, C., Battisti, D. S. \& Kissel, C. Dansgaard-Oeschger cycles: interactions between ocean and sea ice intrinsic to the Nordic seas. Paleoceanography 28, 491-502 (2013).

53. Ezat, M., Rasmussen, T. L. \& Groeneveld, J. Persistent intermediate water warming during cold stadials in the southeastern Nordic seas during the past 65 k.y. Geology 42, 663-666 (2014)

54. Krebs, U. \& Timmermann, A. Tropical air-sea interactions accelerate the recovery of the Atlantic Meridional Overturning Circulation after a major shutdown. J. Clim 20, 4940-4956 (2007).

55. Müller, P. J., Kirst, G., Ruhland, G., von Storch, G. I. \& Rosell-Melé A Calibration of the alkenone paleotemperature index $\mathrm{U}^{\mathrm{k}^{\prime}}{ }_{37}$ based on core-tops from the eastern South Atlantic and the global ocean $\left(60^{\circ} \mathrm{N}-60^{\circ} \mathrm{S}\right)$. Geochim. Cosmochim. Acta 62, 1757-1772 (1998).

56. Tutin, T. G. et al. Flora Europaea. (Cambridge University Press, Cambridge, 1964-1980).

57. Hopkins, J. Different flotation and deposition of conifer and deciduous pollen. Ecology 31, 633-641 (1950).
58. Chmura, G. L., Smirnov, A. \& Campbell, I. D. Pollen transport through distributaries and depositional patterns in coastal waters. Palaeogeogr. Palaeoclimat. Palaeoecol. 149, 257-270 (1999).

59. Naughton, F. et al. Present-day and past (last 25000 years) marine pollen signal off western Iberia. Mar. Micropaleontol. 62, 91-114 (2007).

60. Mudelsee, M. Ramp function regression: a tool for quantifying climate transitions. Comput. Geosci. 26, 293-307 (2000).

61. Mudelsee, M. Break function regression. A tool for quantifying trend changes in climate time series. Eur. Phys. J. Special Topics 174, 49-63 (2009).

62. Goosse, H. et al. Description of the Earth system model of intermediate complexity LOVECLIM version 1.2. Geosci. Model Dev. 3, 603-633 (2010).

63. Berger, A. L. Long-term variations of daily insolation and Quaternary climatic changes. J. Atm. Sci. 35, 2362-2367 (1978).

64. Abe-Ouchi, A., Segawa, S. \& Saito, F. Climatic conditions for modelling the Northern Hemisphere ice sheets throughout the ice age cycle. Clim. Past 3, 423-438 (2007).

65. Ahn, J. \& Brook, E. J. Siple Dome ice reveals two modes of millennial $\mathrm{CO}_{2}$ change during the last ice age. Nat. Commun. 5, 3723 (2014).

66. Pico, T., Creveling, J. R. \& Mitrovica, J. X. Sea-level records from the U.S. mid Atlantic constrain Laurentide Ice Sheet extent during Marine Isotope Stage 3. Nat. Commun. 8, 15612 (2017)

67. Siddall, M., Rohling, E. J., Thompson, W. G. \& Waelbroeck, C. Marine Isotope Stage 3 sea level fluctuations: data synthesis and new outlook. Rev. Geophys. 46, RG4003 (2008).

\section{Acknowledgements}

We thank Russell Drysdale and Eric Wolff for comments on specific aspects of the paper. Financial support was provided by Natural Environment Research Council grants NE/ C514758/1 (to P.C.T., held at the University of Leeds) and NE/J00653X/1 (to D.A.H.), and Australian Research Council grant FT180100606 (to L.M.). E.C. acknowledges financial support from the ChronoClimate project, funded by the Carlsberg Foundation and MME from the Research Council of Norway and from COFUND - Marie Skłodowska-Curie Actions FP7, project numbers 274429 and 223259. B.M. acknowledges support from the CSIC Ramón y Cajal postdoctoral programme RYC-2013-14073 and LINKA20102. We wish to acknowledge use of the Ferret program for generating the maps in Fig. 7 and Supplementary Fig. 2 in this paper. Ferret is a product of NOAA's Pacific Marine Environmental Laboratory (information is available at http://ferret.pmel noaa.gov/Ferret/).

\section{Author contributions}

V.M., L.C.S. and P.C.T. initiated the study. V.M. generated the pollen record, M.J.M.V generated planktonic isotope, faunal and IRD data, B.M. and J.O.G. generated the alkenone data, D.A.H. the XRF data and stable isotope analyses of detrital carbonate, E.C. the Breakfit/Rampfit analyses and L.M. undertook the LOVECLIM model experiments. R.H.R. and M.M.E. provided expert advice on specific aspects of the paper. V.M., L.M., L.C.S. and P.C.T. wrote the paper. All authors contributed to the ideas presented here.

\section{Competing interests}

The authors declare no competing interests.

\section{Additional information}

Supplementary information is available for this paper at https://doi.org/10.1038/s43247020-0006-X.

Correspondence and requests for materials should be addressed to V.M. or P.C.T.

Peer review information Primary handling editor: Joe Aslin

Reprints and permission information is available at http://www.nature.com/reprints

Publisher's note Springer Nature remains neutral with regard to jurisdictional claims in published maps and institutional affiliations. 